Joint Planning recently issued, and said there is a considerable amount of dissatisfaction among technical and engineer officers regarding methods of applying equipment to the Army. "We have men of great scientific ability, great technical experts, good factories and workshops, and skilled craftsmen and mechanics, but we need to make sure that they are being utilized to the best advantage." There should be a chain of technical responsibility from the Army Council down to the units in the field. Viscount Swinton also emphasized that we have the men of ability needed in the various fields, but found fault with the present system of utilizing them. Lord Milne said that the "great necessity at the present moment is a scheme to link together our great advantages in technical science with our requirements in military strategy".

Lord Hankey, who has until recently been much concerned with the co-ordination of resources of man-power in different fields, pointed out that the White Paper shows that great advances have been made at least in the lower stages, in the provision for collaboration, but there is room for further improvement, particularly at the ministerial stage. $\mathrm{He}$ expressed the hope that it would be possible to add a scientific staff to the Joint General Staff. "Each of the Service Departments is already using scientists, and has found them of great value for operational and other purposes. It is obvious that they should also be brought into the central control of the war." This reminds one of the attitude taken by Sir Henry Tizard in his address at the annual luncheon of the Parliamentary and Science Committee (see Nature, Feb. 7, p. 164). He divided the scientific effort in relation to the War into two portions: the tactical and the strategical. With regard to the former, he said that in Great Britain we have nothing to fear from any nation; but the latter is not nearly so sound. The remedy, he said, is "to have scientists working side by side and in the closest collaboration with those who have the administrative and executive responsibility". The weight of opinion, scientific and lay, is clearly on the side of increased participation of science in the strategy of the War.

\section{School Medical Service in War-time}

Is a Chadwick Lecture delivered on May 12, Dr. J. Alison Glover, late senior medical officer, Board of Education, discussed the school medical service in war-time. In the thirty-one years between the inauguration of the school medical service and the outbreak of the present War the service passed from ascertainment and treatment to prevention, and is entering into a fourth phase, the search for "positive health", the appreciation "that it is the legislator's task to frame a society which shall make the good life possible" and so enable every child to reach the highest degree of health and development of which he is inherently capable. These phases are well shown in the changing outlook on nutrition, from the ascertainment and treatment of malnutrition to the striving after optimum nutrition. In this period of thirty-one years, the British school-child has undergone a wonderful metamorphosis for which, though many other factors have had a share, the school medical service has been largely responsible. The school-child of 1939 was bigger, more resistant to disease, cleaner and in every way fitter to stand the strain of total war than his predecessor of 1908 .

The present health of the school-child after two and a half years of war is shown to be well main- tained whether it be judged by clinical assessment of nutrition, average measurements of growth, the incidence of infectious and catarrhal diseases, the incidence of neurosis or the general impression of medical men, nurses or teachers closest in touch with school-children. Much vigilance is, however, necessary. The difficulties which the service encountered from evacuation naturally differed in the reception and evacuation areas. They were increased by the constant ebb and flow of the ceaseless 'driftback', by the interruptions of alerts, by shelter life, appropriation of schools for other purposes, and by the calling up for service with the Forces of medical men, dentists and nurses. The great development of the provision of meals and milk, the intensive campaign for immunization, the conversion of the camps provided by the National Camps Corporation into residential schools, and the great development of the provision for children under five years were also described. Despite some inevitable curtailment the service has continued to render efficient service.

\section{The Association of Scientific Workers}

THe twenty-fifth annual council meeting of the Association of Scientific Workers was held during May 2-3 at the London School of Hygiene under the chairmanship of the president, Mr. R. A. Watson Watt, F.R.S. About two hundred delegates, representing the eightyfour branches into which the membership of almost six thousand is divided, attended the Council. In his opening address Mr. Watson Watt spoke of the remarkable growth of the Association especially since its registration as a trade union, and its affiliation to the T.U.C. Referring to the Conference on "Science and the War Effort" convened by the Association in January last, he said that in spite of the success of that Conference it is necessary to persist if the criticisms made then of the misuse of science in the national effort are to result in practical action.

If any fears have been felt that the remarkable growth of the Association in the trade union field was likely to have diminished its concern to maintain the highest scientific standards, these were set at rest by a number of forceful speeches insisting that the two sides of the Association's work must proceed hand in hand, and resolutions confirming this attitude were carried by an overwhelming majority. Reports were given of the successful action taken by the Association to maintain standards of payment and working conditions in industry, and of the activities of committees dealing with science education, medical services, agriculture, and the proper use of refugee scientific workers. A report was also given of the activities of branches in the work of building up an appreciation of science and scientific method among the general public.

\section{Academy of Sciences of the U.S.S.R.}

Prof. V. Komarov has been re-elected president of the Academy of Sciences of the U.S.S.R.

At the concluding session of the general meeting of the Academy at Sverdlovsk on May 8, the following were elected honorary members : Prof. W. B. Cannon, George Higginson professor of physiology at Harvard Medical School; Sir Henry Dale, president of the Royal Society; Prof. J. B. S. Haldane, Weldon professor of biometry at University College, London; Prof. Ernest O. Lawrence, director of the Radiation Laboratory, University of California; and Prof. Gilbert Newton Lewis, professor of chemistry and dean of the College of Chemistry, University of California. 